\title{
RNA Editing of Serotonin 2C Receptor and Alcohol Intake
}

\author{
Masaki Tanaka ${ }^{*}$ and Yoshihisa Watanabe ${ }^{2}$ \\ ${ }^{1}$ Department of Anatomy and Neurobiology, Graduate School of Medical Science, Kyoto Prefectural University of Medicine, \\ Kyoto, Japan, ${ }^{2}$ Department of Basic Geriatrics, Graduate School of Medical Science, Kyoto Prefectural University \\ of Medicine, Kyoto, Japan
}

OPEN ACCESS

Edited by:

Kathryn A. Cunningham,

The University of Texas Medical Branch at Galveston, United States

Reviewed by:

Ronald B. Emeson, Vanderbilt University, United States Harriet Schellekens, University College Cork, Ireland

*Correspondence: Masaki Tanaka mtanaka@koto.kpu-m.ac.jp

Specialty section: This article was submitted to

Neuropharmacology, a section of the journal

Frontiers in Neuroscience

Received: 10 October 2019 Accepted: 10 December 2019 Published: 14 January 2020

Citation:

Tanaka M and Watanabe Y (2020) RNA Editing of Serotonin $2 \mathrm{C}$ Receptor and Alcohol Intake.

Front. Neurosci. 13:1390 doi: 10.3389/fnins.2019.01390
Serotonin $2 \mathrm{C}$ receptor $\left(5-\mathrm{HT}_{2 \mathrm{C}} \mathrm{R}\right.$ ) belongs to the superfamily of seven transmembrane domain receptors coupled to G proteins (GPCR). It is broadly distributed in the CNS and its expression is relatively high in the limbic system including the amygdala, nucleus accumbens (NAc), hippocampus, and hypothalamus. Based on its expression patterns and numerous pharmacological studies, $5-\mathrm{HT}_{2} \mathrm{C}$ is thought to be involved in various brain functions including emotion, appetite, and motor behavior. Here, we review $5-\mathrm{HT}_{2 \mathrm{C}} \mathrm{R}$ and its relationship with alcohol intake with a particular focus on the involvement of $5-\mathrm{HT}_{2} \mathrm{C}$ mRNA editing and its association with alcohol preference in mice. RNA editing is a post-transcriptional modification mechanism. In mammals, adenosine is converted to inosine by the deamination enzymes ADAR1 and ADAR2. $5-\mathrm{HT}_{2} \mathrm{C}$ is the only GPCR subjected to RNA editing within the coding region. It has five editing sites in exon 5 that encode the second intracellular loop. Consequently, three amino acids residues (1156, N158, and 1160) of the unedited receptor (INI) may be altered to differently edited isoforms, resulting in a change of receptor activity such as 5-HT potency and G-protein coupling. $5-\mathrm{HT}_{2 \mathrm{C}} \mathrm{R}$ in the NAc is involved in enhanced alcohol drinking after chronic alcohol exposure and alterations in $5-\mathrm{HT}_{2} \mathrm{C}$ $m R N A$ editing is important in determining the alcohol preference using different strains of mice and genetically modified mice. RNA editing of this receptor may participate in the development of alcoholism.

Keywords: 5- $\mathrm{HT}_{2 \mathrm{C}} \mathrm{R}$, RNA editing, alcohol intake, nucleus accumbens, mice

\section{INTRODUCTION}

The serotonin $2 \mathrm{C}$ receptor $\left(5-\mathrm{HT}_{2 \mathrm{C}} \mathrm{R}\right)$ is a member of the $5-\mathrm{HT}$ receptor family, which is divided into seven groups from $5-\mathrm{HT}_{1} \mathrm{R}$ to $5-\mathrm{HT}_{7} \mathrm{R}$ (Hoyer et al., 1994). $5-\mathrm{HT}$ is produced in neurons located in specific areas of the brainstem that project axons throughout the central nervous system (CNS) (Dahlstroem and Fuxe, 1964). 5-HT acts as a neurotransmitter via receptors and it is involved in the regulation of emotional control, sleep, appetite, and learning. Many studies have reported the roles of 5-HT in psychiatric disorders such as depression and schizophrenia (Mohammad-Zadeh et al., 2008). The seven 5-HT receptors are further divided into at least 14 subgroups (Barnes and Sharp, 1999). In this review article we describe the general aspects of $5-\mathrm{HT}_{2 \mathrm{C}} \mathrm{R}$, its mRNA editing mechanism, and the relationship between $5-\mathrm{HT}_{2 \mathrm{C}} \mathrm{R}$ and alcohol intake, particularly alterations in $5-\mathrm{HT}_{2} \mathrm{R}$ mRNA editing and alcohol drinking behavior. 


\section{$5-\mathrm{HT}_{2 \mathrm{C}} \mathrm{R}$}

$5-\mathrm{HT}_{2 \mathrm{C}} \mathrm{R}$ belongs to the family of seven transmembrane $\mathrm{G}$ protein coupled receptors (GPCRs). Although it has a similar binding activity to $5-\mathrm{HT}$ in $5-\mathrm{HT}_{1 \mathrm{~A}} \mathrm{R}$ and $5-\mathrm{HT}_{1 \mathrm{~B}} \mathrm{R}$, it forms a family with $5-\mathrm{HT}_{2 \mathrm{~A}} \mathrm{R}$ and $5-\mathrm{HT}_{2 \mathrm{~B}} \mathrm{R}$ due to the similarity of their amino acid sequences. $5-\mathrm{HT}_{2 \mathrm{C}} \mathrm{R}$ has $57 \%$ amino acid identity with $5-\mathrm{HT}_{2 \mathrm{~A}} \mathrm{R}$ (Hoyer et al., 2002). The 5-HT $2 \mathrm{C}$ gene (HTR2C) is located on chromosome Xq24 and harbors multiple introns within its coding regions (Milatovich et al., 1992). In addition to splicing variants, $5-H T_{2} \mathrm{C}$ pre-mRNA undergoes RNA editing at five sites (Fitzgerald et al., 1999; Werry et al., 2008; Chagraoui et al., 2016).

The distribution of $5-\mathrm{HT}_{2 \mathrm{C}} \mathrm{R}$ in the brain indicates its role in a variety of functions. Radioautography by tritium labeling, immunohistochemistry and in situ hybridization have revealed that $5-\mathrm{HT}_{2 \mathrm{C}} \mathrm{R}$ is widely expressed in the CNS but not in the peripheral nervous system (Werry et al., 2008). In the CNS, it is more broadly expressed than $5-\mathrm{HT}_{2 \mathrm{~A}} \mathrm{R}$ and $5-\mathrm{HT}_{2 \mathrm{~B}} \mathrm{R}$. It is strongly expressed in the choroid plexus along the cerebral ventricle (Sanders-Bush and Breeding, 1988), followed by the prefrontal cortex, basal ganglia (caudate nucleus and substantia nigra), and limbic system including the anterior olfactory nucleus, lateral habenular nucleus, hippocampus, amygdala, cingulate cortex, nucleus accumbens, ventral tegmental area (VTA) and hypothalamus in rats (Clemett et al., 2000; Li et al., 2004). In humans, $5-\mathrm{HT}_{2 \mathrm{C}} \mathrm{R}$ was reported to be expressed in the cerebral cortex, cerebellum, and substantia nigra (Pasqualetti et al., 1999). Regarding its intracellular localization, 5- $\mathrm{HT}_{2 \mathrm{C}} \mathrm{R}$ is mainly present in the post-synaptic membrane, but in some brain regions it is expressed in the presynaptic membrane (Becamel et al., 2004). Its distribution in specific brain regions and pharmacological studies using agonists and antagonists of $5-\mathrm{HT}_{2 \mathrm{C}} \mathrm{R}$ revealed it has a role in emotion and hypothalamic function. If the physiological functions of this receptor are disturbed, various diseases such as anxiety, depression, addiction, obesity, and epilepsy may develop (Di Giovanni and De Deurwaerdere, 2016; Palacios et al., 2017). Analyses using HTR2C gene knockout mice also supports this idea (Tecott et al., 1995; Chou-Green et al., 2003). 5-HT 2 C R couples with Gq/11, Ga12/13, and $\mathrm{G} \alpha \mathrm{i}$ and regulates pathways at the second messenger level via inositol-3-phosphate, $\mathrm{Ca}^{2+}$, cAMP, and arachidonic acid. In addition, the activation of cGMP, ERK1/2 and protein kinase $\mathrm{C}$ were also reported to act as second messengers (Berg et al., 1994; Werry et al., 2008). These findings support the idea that a disturbance in one or more of these pathways may cause the development of diseases related to $5-\mathrm{HT}_{2} \mathrm{C}$. Therefore, drug design studies have targeted this receptor. However, this is not simple because $5-\mathrm{HT}_{2 \mathrm{C}} \mathrm{R}$ has constitutive activity in the absence of ligand binding and amino acid changes occur due to mRNA editing and alternative splicing. It was recently reported that the truncated isoform of $5-\mathrm{HT}_{2} \mathrm{CR}$ generated by alternative slicing heterodimerizes with full length $5-\mathrm{HT}_{2} \mathrm{C}$ intracellularly to decrease receptor signaling (Martin et al., 2013; Zhang et al., 2016; Stamm et al., 2017). It was reported that 5-HT2CR also dimerizes with other receptors, which impacts subsequent signaling (Schellekens et al., 2013, 2015).

\section{RNA EDITING of 5-HT $2 \mathrm{C}$ mRNA}

A variety of gene products occurs by post-transcriptional modification even in the same genome. Most well-known alternative splicing occurs in more than $70 \%$ of mammalian genes (Maas et al., 2006). Another modification is mRNA editing. In vertebrates, adenosine of RNA is deaminated to inosine by adenosine deaminase enzymes acting on RNA (ADAR). Inosine is regarded as guanosine when RNA is transcribed because of its structural similarity. ADARs specifically catalyze double strand RNAs. To date, ADAR1, ADAR2, and ADAR3 have been identified, whereas target RNAs of ADAR3 have not been found (Nishikura, 2010). RNA is an energetically unstable molecule, thus it is considered that RNA is edited in order to respond rapidly to a change in the surrounding environment (Tohda, 2014). Most RNA editing occurs in $3^{\prime}$ or $5^{\prime}$ untranslated regions and this regulates gene expression. Less than 30 genes undergo mRNA editing within coding regions (Nishikura, 2010). Human ENCODE RNA-seq data indicate that only 123 editing sites are present in protein-coding sequences (Park et al., 2012). In these cases, a different isoform can be produced after RNA editing. The majority of genes that undergo mRNA editing within exons are ion channels or receptors of neurotransmitters. Among them, two neurotransmitter receptors in the CNS, GluR2/GluA2, a subunit of the AMPA type glutamatergic receptor and $5-\mathrm{HT}_{2 \mathrm{C}} \mathrm{R}$, a GPCR, have been intensively analyzed. GluR2/GluA2, which regulates $\mathrm{Ca}^{2+}$ influx into the cell, undergoes editing at two sites. Glutamine $(\mathrm{Q})$ is substituted to arginine $(\mathrm{R})$ by ADAR2 at the $\mathrm{Q} / \mathrm{R}$ site and arginine is substituted to glycine $(\mathrm{G})$ by ADAR1 and ADAR2 at the R/G site. Usually the $\mathrm{Q} / \mathrm{R}$ site of GluR2 is edited $100 \%$ to inhibit the $\mathrm{Ca}^{2+}$ influx; however, when the editing frequency is decreased, the permeability of $\mathrm{Ca}^{2+}$ into the cell is increased causing neuronal cell death. A decrease of RNA editing at the Q/R site of GluR2 in motor neurons in the anterior horn of the spinal cord was suggested to cause amyotrophic lateral sclerosis (Kwak et al., 2010).

Regarding $5-\mathrm{HT}_{2} \mathrm{C}$, adenosine to inosine editing can occur at five sites (A-E) in exon 5, which encodes a second intracellular loop. The A and B sites are catalyzed by ADAR1 and the D site is catalyzed by ADAR2 (Figure 1A). The $\mathrm{C}$ and $\mathrm{E}$ sites are edited by ADAR1 and 2. The second intracellular loop is an important region for coupling to $G$ proteins, which affects downstream signaling cascades. The presence or absence of editing at each of the five sites results in changes in three amino acid sequences at 156 (isoleucine, I), 158 (asparagine, N), and 160 (isoleucine, I) (Figure 1B). When mRNA editing occurs at A and B sites of the 156 non-edited isoform, isoleucine may change to valine $(\mathrm{V})$ or methionine (M). At $\mathrm{C}$ and $\mathrm{E}$ sites, 158 asparagine may change to aspartic acid (D), serine (S), or glycine (G). At the D site, 160 isoleucine can be substituted to valine $(\mathrm{V})$. If editing happens at all sites, a VGV type isoform is generated. Thus, from the nonedited INI isoform, 24 isoforms can be produced theoretically (Figure 1C) (Wang et al., 2000; Werry et al., 2008). 5- $\mathrm{HT}_{2 \mathrm{C}} \mathrm{R}$ has its own constitutive activity in the absence of ligand binding. The unedited isoform INI has the highest constitutive activity, which is downregulated in edited isoforms (Herrick-Davis et al., 1999; Niswender et al., 1999). Moreover, the sensitivity and binding 


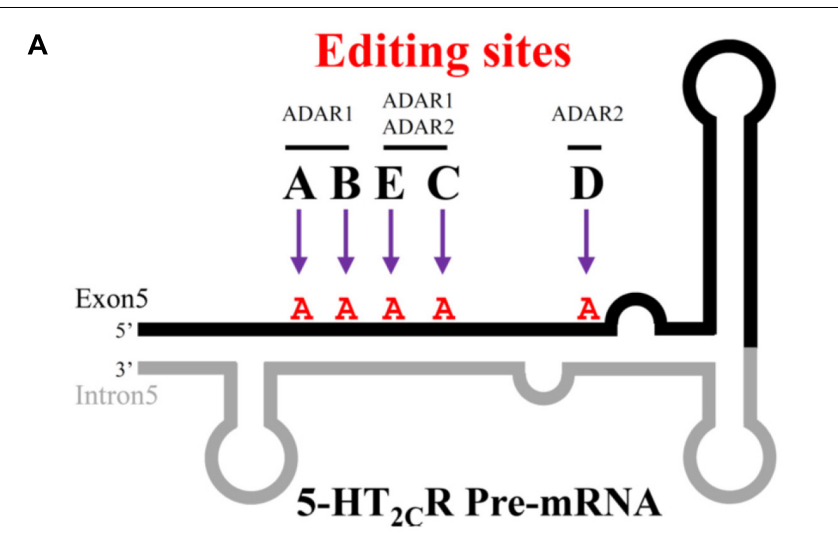

B

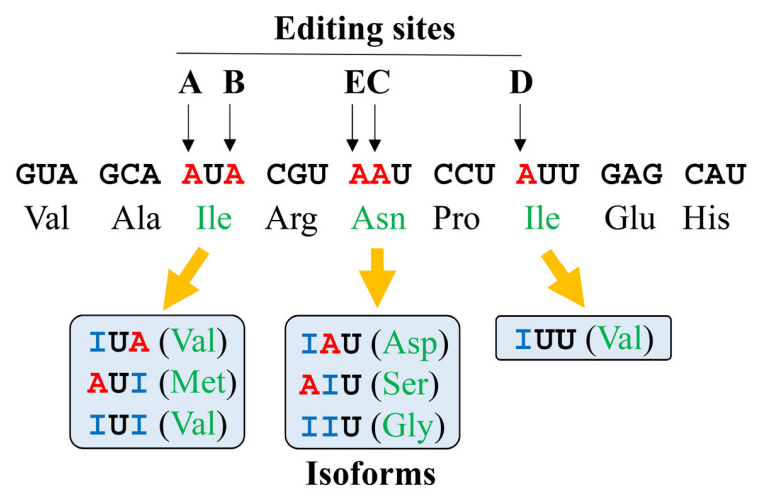

C

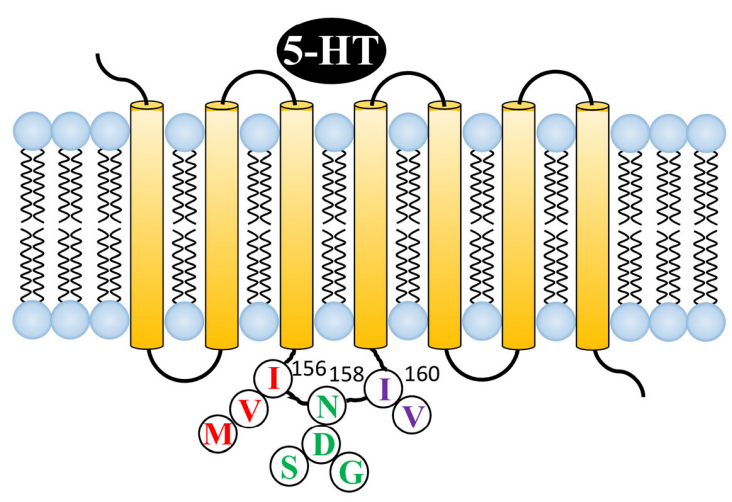

D

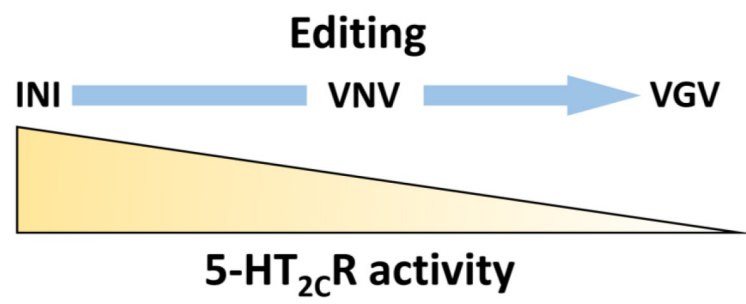

FIGURE 1 | Editing sites at $5-\mathrm{HT}_{2} \mathrm{C}$ R pre-mRNA and various amino acid sequences. (A) Five sites ( $A$ to $E$ ) in exon 5 of $5-\mathrm{HT}_{2 \mathrm{C}} \mathrm{R}$ mRNA. Adenosine to Inosine (A to I) RNA editing occurs in the region where exon 5 makes a double strand with intron 5. Editing enzyme ADAR1 acts on $A$ and $B$ sites, whereas ADAR2 acts on $D$ sites. $E$ and $C$ sites are edited by both ADAR1 and ADAR2.

(Continued)
FIGURE 1 | Continued

(B) The structure of $5-\mathrm{HT}_{2} \mathrm{C}$ has seven transmembrane regions. Three amino acids $(156,158,160)$ in the second intracellular loop may be edited by RNA editing. (C) The variation of edited isoforms. From A and B editing sites, non-edited isoleucine (lle) can be edited to valine (Val) or methionine (Met). Asparagine (An) in $E$ and $C$ sites may be edited to aspartic acid (Asp), serine (Ser), or glycine (Gly). Amino acid isoleucine at the $D$ site may be edited to valine (Val). (D) $5-\mathrm{HT}_{2 \mathrm{C}} \mathrm{R}$ activity is reduced in relation to an increase in RNA editing.

affinity to 5-HT varies dependent on the specific isoform (Burns et al., 1997; Fitzgerald et al., 1999; Berg et al., 2001; Gurevich et al., 2002). We previously examined the activity of each isoform in vitro by measuring the constitutive activity and inositol phosphate productivity after 5-HT stimulation. We observed that the non-edited INI isoform had the highest activities and that the all-edited VGV isoform had the lowest activities (Figure 1D) (Watanabe et al., 2014). Regarding the amount of each isoform, differences among species and brain regions were reported. The most abundant isoform in the whole brain was the VSV isoform in humans and the VNV isoform in rats. In humans, VSV is the major isoform in the thalamus, hypothalamus, and amygdala; however, ISV and VSI are the major isoforms in the cerebellum and hippocampus, respectively (Wang et al., 2000). Recently, it was reported that VSV was the predominant isoform in many regions except INI in the cerebellum of the porcine brain (Larsen et al., 2016). We examined the isoforms in three mouse strains: VNV was the most abundant in the nucleus accumbens (NAc), dorsal raphe nucleus (DRN) and amygdala (Hackler et al., 2006). The second most common isoform was VSV in the NAc and VNI in the DRN suggesting regional differences (Wang et al., 2000).

Taken together, these findings suggest that $5-\mathrm{HT}_{2} \mathrm{C}$ editing may be involved in emotional and psychiatric disorders. Patients with these disorders might have an altered frequency of $5-\mathrm{HT}_{2} \mathrm{CR}$ RNA editing. Indeed, many studies have reported that $5-\mathrm{HT}_{2 \mathrm{C}} \mathrm{R}$ RNA editing was altered in patients with major depression or in suicide victims (Niswender et al., 2001; Gurevich et al., 2002; Iwamoto and Kato, 2003; Dracheva et al., 2008; Simmons et al., 2010; Di Narzo et al., 2014; Weissmann et al., 2016). In schizophrenia patients, $5-\mathrm{HT}_{2} \mathrm{C}$ RNA editing was reduced in the frontal cortex (Sodhi et al., 2001). Anxiety and stress conditions also may be related to $5-\mathrm{HT}_{2} \mathrm{C}$ R RA editing (Englander et al., 2005; Mombereau et al., 2010; Bombail et al., 2014). In addition to mental distress, editing changes in $5-\mathrm{HT}_{2 \mathrm{C}} \mathrm{R}$ mRNA were reported to be involved in obesity, and spinal cord and peripheral nerve injury (Morabito et al., 2010; Schellekens et al., 2012; Uchida et al., 2017).

Recently, the gut microbiota was reported to influence 5$\mathrm{HT}_{2 \mathrm{C}} \mathrm{R}$ mRNA editing levels during development in mouse brain (van de Wouw et al., 2019). Early life stress related to maternal separation induced increased depression-like behavior and $5-\mathrm{HT}_{2} \mathrm{C}$ RNA editing during mouse adulthood (Bhansali et al., 2007). Moreover, alterations in editing might occur trans-generationally. It was reported that chronic unpredictable stress in pre-reproductive female rats affected the $5-\mathrm{HT}_{2 \mathrm{C}} \mathrm{R}$ RNA editing in two generations of offspring (Zaidan et al., 2018). Maternal treatment with a serotonin-specific reuptake 
inhibitor (SSRI), fluoxetine, after stress reversed the effect of these editing changes in the prefrontal cortex and amygdala of new born offspring (Zaidan and Gaisler-Salomon, 2015). Collectively, environmental conditions that affect the editing of $5-\mathrm{HT}_{2 \mathrm{C}} \mathrm{R}$ mRNA with its receptor function might be therapeutic targets of disease.

\section{ALCOHOL DRINKING BEHAVIOR AND $5-\mathrm{HT}_{2 \mathrm{C}} \mathrm{R}$}

It is generally thought that alcohol is consumed for its positive reinforcing effects and that chronic exposure to alcohol results in adaptations with abnormal drinking patterns. The mesolimbic dopaminergic projections from the VTA to the NAc in the midbrain have been implicated in playing an essential role in the brain reward system (Engel and Jerlhag, 2014). Dopaminergic dysfunction in the NAc caused by chronic alcohol consumption is involved in alcoholism (Heinz, 2002). One of the modulating factors of this VTA-NAc dopaminergic system

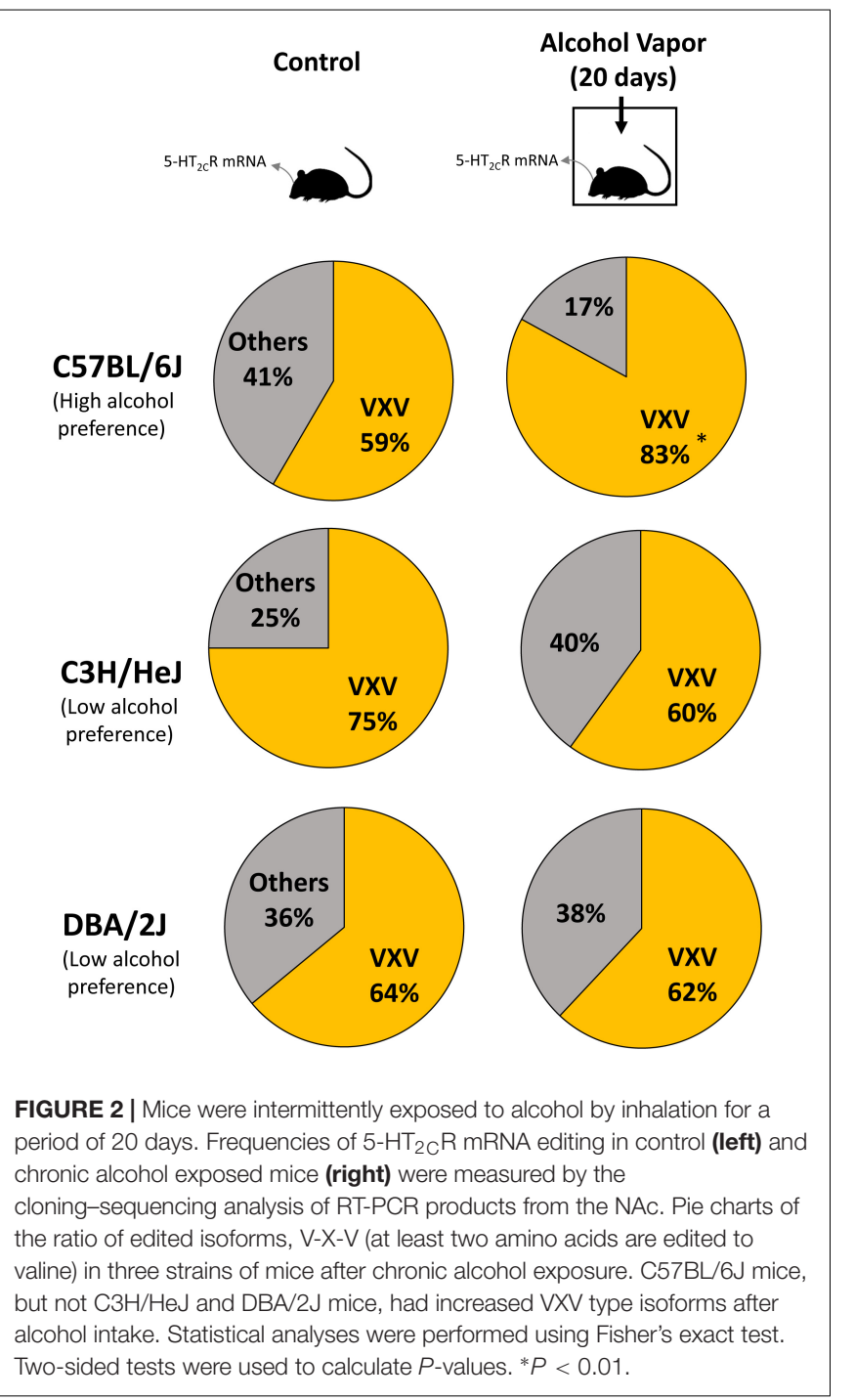

is 5-HT from neurons of the DRN (Yoshimoto and McBride, 1992). 5-HT stimulates the alcohol-induced excitation of VTA neurons (Brodie et al., 1995). Chronic alcohol exposure affects serotonergic synaptic transmission and causes adaptive changes in its receptors. $5-\mathrm{HT}_{2 \mathrm{C}} \mathrm{R}$ appears to undergo such adaptive changes (Pandey et al., 1995; Lovinger, 1997). Treatment of the NAc with a $5-\mathrm{HT}_{2} \mathrm{C}$ antagonist inhibited alcohol-induced behavioral sensitization in mice (Andrade et al., 2011). We previously reported that among 5 - $\mathrm{HT}$ receptors, $5-\mathrm{HT}_{2} \mathrm{C}$ in the NAc was involved in increased alcohol drinking behavior of C57BL/6J mice after chronic alcohol exposure (Yoshimoto et al., 2012). We developed a chronic alcohol exposure animal model via the inhalation of vapored ethanol. After chronic exposure to alcohol, mice had a higher alcohol intake compared with control animals, whereas their water consumption was similar to that of the control group. These mice had an enhanced expression of $5-\mathrm{HT}_{2} \mathrm{C}$ at the mRNA and protein levels in the NAc. The expression of $5-\mathrm{HT}_{7} \mathrm{R}$ mRNA in the NAc was also increased; however, only systemic treatment with a specific $5-\mathrm{HT}_{2 \mathrm{C}} \mathrm{R}$ antagonist or intra NAc treatment inhibited the enhanced alcohol intake after chronic alcohol exposure (Yoshimoto et al., 2012).

Previous studies reported differences in alcohol preference among mouse inbred strains. C57BL/6J, but not $\mathrm{C} 3 \mathrm{H} / \mathrm{HeJ}$ and DBA/2J mice, drank more alcohol after alcohol exposure compared with controls (Yoshimoto and Komura, 1989). The expression of $5-\mathrm{HT}_{2} \mathrm{C}$ mRNA was increased in the NAc of $\mathrm{C} 57 \mathrm{BL} / 6 \mathrm{~J}$ mice but in $\mathrm{C} 3 \mathrm{H} / \mathrm{HeJ}$ or $\mathrm{DBA} / 2 \mathrm{~J}$ mice. As $5-\mathrm{HT}_{2} \mathrm{CR}$ is subjected to pre mRNA editing, we examined the editing frequency of $5-\mathrm{HT}_{2 \mathrm{C}} \mathrm{R}$ mRNA. In $\mathrm{C} 57 \mathrm{BL} / 6 \mathrm{~J}$ mice, edited isoforms of $5-\mathrm{HT}_{2} \mathrm{CR}$ were increased in the NAc but not the hippocampus. Particularly, VXV isoforms such as VGV, VNV, VSV, and VDV in which the first (156) and third (160) of three replaceable amino acids were edited to valine, were increased in C57BL/6J mice after chronic alcohol exposure; however, these increases were not observed in $\mathrm{C} 3 \mathrm{H} / \mathrm{HeJ}$ or $\mathrm{DBA} / 2 \mathrm{~J}$ mice (Figure 2 and Table 1). The editing enzymes ADAR1 and ADAR2 were increased in the NAc of C57BL/6J mice after chronic

TABLE 1 | Frequencies of 5-HT $2 \mathrm{C}$ R isoforms in C57BL/6J mice.

\begin{tabular}{|c|c|c|c|c|}
\hline \multirow{3}{*}{$\begin{array}{l}\text { Isoforms } \\
\mathrm{I}-\mathrm{N}-\mathrm{I}\end{array}$} & \multicolumn{4}{|c|}{ NAc of C57BL/6J } \\
\hline & \multicolumn{2}{|c|}{ Control } & \multicolumn{2}{|c|}{ Alcohol } \\
\hline & $3 \%$ & & $3 \%$ & \\
\hline |-S-I & $0 \%$ & & $0 \%$ & \\
\hline I-N-V & $5 \%$ & & $0 \%$ & \\
\hline I-G-V & $0 \%$ & & $0 \%$ & \\
\hline V-G-I & $2 \%$ & & $2 \%$ & \\
\hline $\mathrm{V}-\mathrm{N}-\mathrm{I}$ & $21 \%$ & & $7 \%$ & \\
\hline V-S-I & $10 \%$ & & $5 \%$ & \\
\hline V-D-I & $0 \%$ & & $0 \%$ & \\
\hline$V-G-V$ & $2 \%$ & $V-X-V$ & $2 \%$ & $V-X-V$ \\
\hline $\mathrm{V}-\mathrm{N}-\mathrm{V}$ & $40 \%$ & $59 \%$ & $62 \% P<0.05$ & $83 \%$ \\
\hline V-S-V & $16 \%$ & & $10 \%$ & $P<0.01$ \\
\hline V-D-V & $2 \%$ & & $9 \%$ & \\
\hline
\end{tabular}

Statistical analyses were performed by Fisher's exact test. Two-sided tests were used to calculate P-values. Reproduced partly with permission by Oxford University Press (Watanabe et al., 2014). 
alcohol exposure but not in $\mathrm{C} 3 \mathrm{H} / \mathrm{HeJ}$ or DBA/2J mice. Taken together, C57BL/6J mice showed enhanced alcohol intake after chronic alcohol exposure related to the increased RNA editing of $5-\mathrm{HT}_{2} \mathrm{C}$; however, this was not observed in $\mathrm{C} 3 \mathrm{H} / \mathrm{HeJ}$ or DBA/2J mice that did not show enhanced alcohol intake. From this result, alterations in the RNA editing of $5-\mathrm{HT}_{2 \mathrm{C}} \mathrm{R}$ may underlie alcohol preference. Next, we examined mice that exclusively expressed the non-edited INI isoform of $5-\mathrm{HT}_{2 \mathrm{C}} \mathrm{R}$ (Kawahara et al., 2008) and compared them with wild type littermates on the C57BL/6J background. ADARs recognize double-stranded RNA. Exon 5 of the $5-\mathrm{HT}_{2} \mathrm{C}$ mRNA consists of an imperfect double-stranded RNA with intron 5 . Intron 5 was deleted in INI knock-in mice to prevent editing by ADARs at five sites in exon 5. INI mice had a similar phenotype of food intake, water intake and weight gain as wild type mice. We examined alcohol consumption in INI and wild type mice after chronic alcohol exposure and observed that wild type mice had an increase in alcohol intake; however, INI mice had a similar level of alcohol intake to the controls even on the $\mathrm{C} 57 \mathrm{BL} / 6 \mathrm{~J}$ background. This result indicates that the editing of $5-\mathrm{HT}_{2} \mathrm{CR}$ mRNA underlies the increase in alcohol consumption after chronic alcohol exposure in mice. The importance of RNA editing in alcohol preference was confirmed using non-changing RNA editing (INI) mice. The constitutive activity of $5-\mathrm{HT}_{2} \mathrm{C}$ inhibits accumbal dopamine release (De Deurwaerdere et al., 2004; Di Matteo et al., 2004). 5- $\mathrm{HT}_{2 \mathrm{C}} \mathrm{R}$ in the NAc is expressed in GABAergic neurons as well as in the VTA, DRN, and medial prefrontal cortex (Bubar et al., 2011; Spoida et al., 2014; Nocjar et al., 2015; Aoki et al., 2016). It was reported that the GABA neuronal system was also involved in alcohol reward and dependence (Koob et al., 1998). Increased edited isoforms of $5-\mathrm{HT}_{2} \mathrm{C}$ with low signaling induced by chronic alcohol exposure may enhance dopamine release by modulating GABAergic neurons in the NAc. Consequently, mice may develop increased alcohol consumption. Although the mesolimbic dopamine system is modulated by $5-\mathrm{HT}_{2 \mathrm{C}} \mathrm{R}$ (Di Giovanni and De Deurwaerdere, 2016; De Deurwaerdere and Di Giovanni, 2017) and its RNA editing seems to affect the addiction to drugs, few studies have investigated the relationship between them. Cocaine administration to the rat cerebral cortex for 7 days did not alter the RNA editing of $5-\mathrm{HT}_{2 \mathrm{C}} \mathrm{R}$ in the cerebral cortex, hippocampus or midbrain (Iwamoto and Kato, 2002). Nicotine withdrawal reduced editing at the $E$ site in the hippocampus of rats (Zaniewska et al., 2015). Further studies are necessary to reveal the role of RNA editing of $5-\mathrm{HT}_{2 \mathrm{C}} \mathrm{R}$ in drug addiction in the future.

Among each of the editing sites $(\mathrm{A}-\mathrm{E})$ of $5-\mathrm{HT}_{2 \mathrm{C}} \mathrm{R}$ in the $\mathrm{NAc}$, the editing frequency at the $\mathrm{D}$ site, an ADAR2 specific site, was significantly increased in C57BL/6J mice after chronic alcohol exposure. ADAR2 expression was enhanced as well as ADAR1 in the NAc (Watanabe et al., 2014). Regarding RNA

\section{REFERENCES}

Andrade, A. L., Abrahao, K. P., Goeldner, F. O., and Souza-Formigoni, M. L. (2011). Administration of the 5-HT2C receptor antagonist SB-242084 into the nucleus accumbens blocks the expression of ethanol-induced behavioral sensitization in Albino Swiss mice. Neuroscience 189, 178-186. doi: 10.1016/j.neuroscience. 2011.05.028 editing in the NAc, GluA2 RNA editing at the Q/R site in the NAc was reduced by forced cocaine abstinence, and ADAR2 overexpression in the NAc attenuated cocaine-seeking behavior (Schmidt et al., 2015). We examined the involvement of RNA editing in alcohol drinking by deleting ADAR2 in the NAc using conditional ADAR2 knockout mice (ADAR2 $2^{\text {flox }} /$ flox $)$ on a C57BL/6J genetic background (Hideyama et al., 2010). Adenoassociated virus (AAV)-green fluorescent protein (GFP)/Cre into the NAc of ADAR2 $2^{\text {flox } / \text { flox }}$ mice was used to specifically delete the ADAR2 gene. Accumbal RNA editing frequency in the ADAR2dependent editing sites of GluA2 Q/R, 5- $\mathrm{HT}_{2 \mathrm{C}} \mathrm{R}$ site $\mathrm{D}$ and CYFIP2 K/E, was significantly reduced (Shirahase et al., 2018). In contrast to wild type mice, ADAR2 $\mathrm{KO}$ mice did not develop enhanced ethanol intake or ethanol preference after chronic exposure to ethanol vapor (Shirahase et al., 2018). ADAR2 mediates the RNA editing of various ion channels and receptors such as the $\mathrm{Ca}_{\mathrm{V}} 1.3$ calcium ion channel, $\mathrm{K}_{\mathrm{V}} 1.1$ potassium ion channel, 5- $\mathrm{HT}_{2 \mathrm{C}} \mathrm{R}$, GluA2, and GABA (Bhalla et al., 2004; Bazzazi et al., 2013; Behm and Ohman, 2016). Therefore, other receptors as well as $5-\mathrm{HT}_{2} \mathrm{C}$ may be involved in the alcohol drinking behavior of this model by a NAc-specific reduction of ADAR2 expression. Increased cortical expression of ADAR2 and $5-\mathrm{HT}_{2 \mathrm{C}} \mathrm{R}$ mRNA editing was reported in major depressive suicide victims (Simmons et al., 2010). ADAR2 is highly expressed in the brain and its degradation is regulated by E3 ubiquitin ligase WWP2 (Marcucci et al., 2011; Gallo et al., 2017). Therefore, control of the ADAR2 level in the NAc might be a target for the development of treatment for alcoholism.

\section{CONCLUSION}

We reviewed the general features of $5-\mathrm{HT}_{2} \mathrm{C}$ and its mRNA editing with specific reference to alcohol preference. The accumbal expression and mRNA editing of $5-\mathrm{HT}_{2} \mathrm{C}$ is involved in alcohol intake in mice and this mechanism may be also relevant to human alcoholism. The regulation of $5-\mathrm{HT}_{2} \mathrm{C}$ RNA editing might be a new therapeutic strategy for alcohol addiction.

\section{AUTHOR CONTRIBUTIONS}

MT conceived the review and wrote the manuscript. YW prepared figures and table.

\section{FUNDING}

This work was supported by Grants-in-Aid for Scientific Research from the Japan Society for the Promotion of Science (grant numbers 25290014 and 17H03553) to MT.

Aoki, M., Watanabe, Y., Yoshimoto, K., Tsujimura, A., Yamamoto, T., Kanamura, N., et al. (2016). Involvement of serotonin $2 \mathrm{C}$ receptor RNA editing in accumbal neuropeptide Y expression and behavioural despair. Eur. J. Neurosci. 43, 12191228. doi: 10.1111/ejn.13233

Barnes, N. M., and Sharp, T. (1999). A review of central 5-HT receptors and their function. Neuropharmacology 38, 1083-1152. doi: 10.1016/s0028-3908(99) 00010-6 
Bazzazi, H., Ben Johny, M., Adams, P. J., Soong, T. W., and Yue, D. T. (2013). Continuously tunable $\mathrm{Ca}(2+)$ regulation of RNA-edited Cav 1.3 channels. Cell Rep. 5, 367-377. doi: 10.1016/j.celrep.2013.09.006

Becamel, C., Gavarini, S., Chanrion, B., Alonso, G., Galeotti, N., Dumuis, A., et al. (2004). The serotonin 5-HT2A and 5-HT2C receptors interact with specific sets of PDZ proteins. J. Biol. Chem. 279, 20257-20266.

Behm, M., and Ohman, M. (2016). RNA editing: a contributor to neuronal dynamics in the mammalian brain. Trends Genet. 32, 165-175. doi: 10.1016/ j.tig.2015.12.005

Berg, K. A., Clarke, W. P., Sailstad, C., Saltzman, A., and Maayani, S. (1994). Signal transduction differences between 5-hydroxytryptamine type 2A and type 2C receptor systems. Mol. Pharmacol. 46, 477-484.

Berg, K. A., Cropper, J. D., Niswender, C. M., Sanders-Bush, E., Emeson, R. B., and Clarke, W. P. (2001). RNA-editing of the 5-HT(2C) receptor alters agonistreceptor-effector coupling specificity. Br. J. Pharmacol. 134, 386-392. doi: 10. 1038/sj.bjp.0704255

Bhalla, T., Rosenthal, J. J., Holmgren, M., and Reenan, R. (2004). Control of human potassium channel inactivation by editing of a small mRNA hairpin. Nat. Struct. Mol. Biol. 11, 950-956. doi: 10.1038/nsmb825

Bhansali, P., Dunning, J., Singer, S. E., David, L., and Schmauss, C. (2007). Early life stress alters adult serotonin $2 \mathrm{C}$ receptor pre-mRNA editing and expression of the alpha subunit of the heterotrimeric G-protein G q. J. Neurosci. 27, 1467-1473. doi: 10.1523/JNEUROSCI.4632-06.2007

Bombail, V., Qing, W., Chapman, K. E., and Holmes, M. C. (2014). Prevention of 5hydroxytryptamine $2 \mathrm{C}$ receptor RNA editing and alternate splicing in C57BL/6 mice activates the hypothalamic-pituitary-adrenal axis and alters mood. Eur. J. Neurosci. 40, 3663-3673. doi: 10.1111/ejn.12727

Brodie, M. S., Trifunovic, R. D., and Shefner, S. A. (1995). Serotonin potentiates ethanol-induced excitation of ventral tegmental area neurons in brain slices from three different rat strains. J. Pharmacol. Exp. Ther. 273, 1139-1146.

Bubar, M. J., Stutz, S. J., and Cunningham, K. A. (2011). 5-HT(2C) receptors localize to dopamine and GABA neurons in the rat mesoaccumbens pathway. PLoS One 6:e20508. doi: 10.1371/journal.pone.0020508

Burns, C. M., Chu, H., Rueter, S. M., Hutchinson, L. K., Canton, H., Sanders-Bush, E., et al. (1997). Regulation of serotonin-2C receptor G-protein coupling by RNA editing. Nature 387, 303-308. doi: 10.1038/387303a0

Chagraoui, A., Thibaut, F., Skiba, M., Thuillez, C., and Bourin, M. (2016). 5-HT2C receptors in psychiatric disorders: a review. Prog. Neuropsychopharmacol. Biol. Psychiatry 66, 120-135. doi: 10.1016/j.pnpbp.2015.12.006

Chou-Green, J. M., Holscher, T. D., Dallman, M. F., and Akana, S. F. (2003). Repeated stress in young and old 5-HT(2C) receptor knockout mice. Physiol. Behav. 79, 217-226. doi: 10.1016/s0031-9384(03)00096-9

Clemett, D. A., Punhani, T., Duxon, M. S., Blackburn, T. P., and Fone, K. C. (2000). Immunohistochemical localisation of the 5-HT2C receptor protein in the rat CNS. Neuropharmacology 39, 123-132. doi: 10.1016/s0028-3908(99)00086-6

Dahlstroem, A., and Fuxe, K. (1964). Evidence for the existence of monoaminecontaining neurons in the central nervous system. I. Demonstration of monoamines in the cell bodies of brain stem neurons. Acta Physiol. Scand. Suppl. 232, 1-55.

De Deurwaerdere, P., and Di Giovanni, G. (2017). Serotonergic modulation of the activity of mesencephalic dopaminergic systems: therapeutic implications. Prog. Neurobiol. 151, 175-236. doi: 10.1016/j.pneurobio.2016.03.004

De Deurwaerdere, P., Navailles, S., Berg, K. A., Clarke, W. P., and Spampinato, U. (2004). Constitutive activity of the serotonin2C receptor inhibits in vivo dopamine release in the rat striatum and nucleus accumbens. J. Neurosci. 24, 3235-3241. doi: 10.1523/jneurosci.0112-04.2004

Di Giovanni, G., and De Deurwaerdere, P. (2016). New therapeutic opportunities for 5-HT2C receptor ligands in neuropsychiatric disorders. Pharmacol. Ther. 157, 125-162. doi: 10.1016/j.pharmthera.2015.11.009

Di Matteo, V., Pierucci, M., and Esposito, E. (2004). Selective stimulation of serotonin $2 \mathrm{c}$ receptors blocks the enhancement of striatal and accumbal dopamine release induced by nicotine administration. J. Neurochem. 89, 418429. doi: 10.1111/j.1471-4159.2004.02337.x

Di Narzo, A. F., Kozlenkov, A., Roussos, P., Hao, K., Hurd, Y., Lewis, D. A., et al. (2014). A unique gene expression signature associated with serotonin $2 \mathrm{C}$ receptor RNA editing in the prefrontal cortex and altered in suicide. Hum. Mol. Genet. 23, 4801-4813. doi: 10.1093/hmg/ddu195
Dracheva, S., Patel, N., Woo, D. A., Marcus, S. M., Siever, L. J., and Haroutunian, V. (2008). Increased serotonin $2 \mathrm{C}$ receptor mRNA editing: a possible risk factor for suicide. Mol. Psychiatry 13, 1001-1010. doi: 10.1038/sj.mp.4002081

Engel, J. A., and Jerlhag, E. (2014). Alcohol: mechanisms along the mesolimbic dopamine system. Prog. Brain Res. 211, 201-233. doi: 10.1016/B978-0-44463425-2.00009-X

Englander, M. T., Dulawa, S. C., Bhansali, P., and Schmauss, C. (2005). How stress and fluoxetine modulate serotonin $2 \mathrm{C}$ receptor pre-mRNA editing. J. Neurosci. 25, 648-651. doi: 10.1523/jneurosci.3895-04.2005

Fitzgerald, L. W., Iyer, G., Conklin, D. S., Krause, C. M., Marshall, A., Patterson, J. P., et al. (1999). Messenger RNA editing of the human serotonin 5-HT2C receptor. Neuropsychopharmacology 21(Suppl. 2), 82S-90S. doi: 10.1016/s0893133x(99)00004-4

Gallo, A., Vukic, D., Michalik, D., O’Connell, M. A., and Keegan, L. P. (2017). ADAR RNA editing in human disease; more to it than meets the I. Hum. Genet. 136, 1265-1278. doi: 10.1007/s00439-017-1837-0

Gurevich, I., Englander, M. T., Adlersberg, M., Siegal, N. B., and Schmauss, C. (2002). Modulation of serotonin 2C receptor editing by sustained changes in serotonergic neurotransmission. J. Neurosci. 22, 10529-10532. doi: 10.1523/ jneurosci.22-24-10529.2002

Hackler, E. A., Airey, D. C., Shannon, C. C., Sodhi, M. S., and Sanders-Bush, E. (2006). 5-HT(2C) receptor RNA editing in the amygdala of C57BL/6J, DBA/2J, and BALB/cJ mice. Neurosci. Res. 55, 96-104. doi: 10.1016/j.neures.2006.02.005

Heinz, A. (2002). Dopaminergic dysfunction in alcoholism and schizophreniapsychopathological and behavioral correlates. Eur. Psychiatry 17, 9-16. doi: 10.1016/s0924-9338(02)00628-4

Herrick-Davis, K., Grinde, E., and Niswender, C. M. (1999). Serotonin 5-HT2C receptor RNA editing alters receptor basal activity: implications for serotonergic signal transduction. J. Neurochem. 73, 1711-1717. doi: 10.1046/j.1471-4159. 1999.731711.x

Hideyama, T., Yamashita, T., Suzuki, T., Tsuji, S., Higuchi, M., Seeburg, P. H., et al. (2010). Induced loss of ADAR2 engenders slow death of motor neurons from Q/R site-unedited GluR2. J. Neurosci. 30, 11917-11925. doi: 10.1523/ JNEUROSCI.2021-10.2010

Hoyer, D., Clarke, D. E., Fozard, J. R., Hartig, P. R., Martin, G. R., Mylecharane, E. J., et al. (1994). International union of pharmacology classification of receptors for 5-hydroxytryptamine (Serotonin). Pharmacol. Rev. 46, 157-203.

Hoyer, D., Hannon, J. P., and Martin, G. R. (2002). Molecular, pharmacological and functional diversity of 5-HT receptors. Pharmacol. Biochem. Behav. 71, 533-554. doi: 10.1016/s0091-3057(01)00746-8

Iwamoto, K., and Kato, T. (2002). Effects of cocaine and reserpine administration on RNA editing of rat 5-HT2C receptor estimated by primer extension combined with denaturing high-performance liquid chromatography. Pharmacogenomics J. 2, 335-340. doi: 10.1038/sj.tpj.6500130

Iwamoto, K., and Kato, T. (2003). RNA editing of serotonin 2C receptor in human postmortem brains of major mental disorders. Neurosci. Lett. 346, 169-172. doi: 10.1016/s0304-3940(03)00608-6

Kawahara, Y., Grimberg, A., Teegarden, S., Mombereau, C., Liu, S., Bale, T. L., et al. (2008). Dysregulated editing of serotonin 2C receptor mRNAs results in energy dissipation and loss of fat mass. J. Neurosci. 28, 12834-12844. doi: 10.1523/jneurosci.3896-08.2008

Koob, G. F., Roberts, A. J., Schulteis, G., Parsons, L. H., Heyser, C. J., Hyytia, P., et al. (1998). Neurocircuitry targets in ethanol reward and dependence. Alcohol. Clin. Exp. Res. 22, 3-9. doi: 10.1111/j.1530-0277.1998.tb03611.x

Kwak, S., Hideyama, T., Yamashita, T., and Aizawa, H. (2010). AMPA receptormediated neuronal death in sporadic ALS. Neuropathology 30, 182-188. doi: 10.1111/j.1440-1789.2009.01090.x

Larsen, K., Momeni, J., Farajzadeh, L., and Bendixen, C. (2016). Differential A-toI RNA editing of the serotonin-2C receptor G-protein-coupled, HTR2C, in porcine brain tissues. Biochimie 121, 189-196. doi: 10.1016/j.biochi.2015.12.011

Li, Q. H., Nakadate, K., Tanaka-Nakadate, S., Nakatsuka, D., Cui, Y., and Watanabe, Y. (2004). Unique expression patterns of 5-HT2A and 5-HT2C receptors in the rat brain during postnatal development: western blot and immunohistochemical analyses. J. Comp. Neurol. 469, 128-140. doi: 10.1002/ cne. 11004

Lovinger, D. M. (1997). Serotonin's role in alcohol's effects on the brain. Alcohol Health Res. World 21, 114-120. 
Maas, S., Kawahara, Y., Tamburro, K. M., and Nishikura, K. (2006). A-to-I RNA editing and human disease. RNA Biol. 3, 1-9. doi: 10.4161/rna.3.1.2495

Marcucci, R., Brindle, J., Paro, S., Casadio, A., Hempel, S., Morrice, N., et al. (2011). Pin1 and WWP2 regulate GluR2 Q/R site RNA editing by ADAR2 with opposing effects. EMBO J. 30, 4211-4222. doi: 10.1038/emboj.2011.303

Martin, C. B., Ramond, F., Farrington, D. T., Aguiar, A. S. Jr., Chevarin, C., Berthiau, A. S., et al. (2013). RNA splicing and editing modulation of 5-HT(2C) receptor function: relevance to anxiety and aggression in VGV mice. Mol. Psychiatry 18, 656-665. doi: 10.1038/mp.2012.171

Milatovich, A., Hsieh, C. L., Bonaminio, G., Tecott, L., Julius, D., and Francke, U. (1992). Serotonin receptor 1c gene assigned to X chromosome in human (band q24) and mouse (bands D-F4). Hum. Mol. Genet. 1, 681-684. doi: 10.1093/hmg/1.9.681

Mohammad-Zadeh, L. F., Moses, L., and Gwaltney-Brant, S. M. (2008). Serotonin: a review. J. Vet. Pharmacol. Ther. 31, 187-199. doi: 10.1111/j.1365-2885.2008. 00944.x

Mombereau, C., Kawahara, Y., Gundersen, B. B., Nishikura, K., and Blendy, J. A. (2010). Functional relevance of serotonin 2C receptor mRNA editing in antidepressant- and anxiety-like behaviors. Neuropharmacology 59, 468-473. doi: 10.1016/j.neuropharm.2010.06.009

Morabito, M. V., Abbas, A. I., Hood, J. L., Kesterson, R. A., Jacobs, M. M., Kump, D. S., et al. (2010). Mice with altered serotonin 2C receptor RNA editing display characteristics of Prader-Willi syndrome. Neurobiol. Dis. 39, 169-180. doi: 10.1016/j.nbd.2010.04.004

Nishikura, K. (2010). Functions and regulation of RNA editing by ADAR deaminases. Annu. Rev. Biochem. 79, 321-349. doi: 10.1146/annurev-biochem060208-105251

Niswender, C. M., Copeland, S. C., Herrick-Davis, K., Emeson, R. B., and SandersBush, E. (1999). RNA editing of the human serotonin 5-hydroxytryptamine 2C receptor silences constitutive activity. J. Biol. Chem. 274, 9472-9478. doi: $10.1074 / j b c .274 .14 .9472$

Niswender, C. M., Herrick-Davis, K., Dilley, G. E., Meltzer, H. Y., Overholser, J. C., Stockmeier, C. A., et al. (2001). RNA editing of the human serotonin 5-HT2C receptor. Alterations in suicide and implications for serotonergic pharmacotherapy. Neuropsychopharmacology 24, 478-491. doi: 10.1016/s0893$133 \mathrm{x}(00) 00223-2$

Nocjar, C., Alex, K. D., Sonneborn, A., Abbas, A. I., Roth, B. L., and Pehek, E. A. (2015). Serotonin-2C and -2a receptor co-expression on cells in the rat medial prefrontal cortex. Neuroscience 297, 22-37. doi: 10.1016/j.neuroscience.2015. 03.050

Palacios, J. M., Pazos, A., and Hoyer, D. (2017). A short history of the 5HT2C receptor: from the choroid plexus to depression, obesity and addiction treatment. Psychopharmacology 234, 1395-1418. doi: 10.1007/s00213-017$4545-5$

Pandey, S. C., Davis, J. M., and Pandey, G. N. (1995). Phosphoinositide systemlinked serotonin receptor subtypes and their pharmacological properties and clinical correlates. J. Psychiatry Neurosci. 20, 215-225.

Park, E., Williams, B., Wold, B. J., and Mortazavi, A. (2012). RNA editing in the human ENCODE RNA-seq data. Genome Res. 22, 1626-1633. doi: 10.1101/gr. 134957.111

Pasqualetti, M., Ori, M., Castagna, M., Marazziti, D., Cassano, G. B., and Nardi, I. (1999). Distribution and cellular localization of the serotonin type 2C receptor messenger RNA in human brain. Neuroscience 92, 601-611. doi: 10.1016/ s0306-4522(99)00011-1

Sanders-Bush, E., and Breeding, M. (1988). Putative selective 5-HT-2 antagonists block serotonin 5-HT-1c receptors in the choroid plexus. J. Pharmacol. Exp. Ther. 247, 169-173.

Schellekens, H., Clarke, G., Jeffery, I. B., Dinan, T. G., and Cryan, J. F. (2012). Dynamic 5-HT2C receptor editing in a mouse model of obesity. PLoS One 7:e32266. doi: 10.1371/journal.pone.0032266

Schellekens, H., De Francesco, P. N., Kandil, D., Theeuwes, W. F., McCarthy, T., van Oeffelen, W. E., et al. (2015). Ghrelin's orexigenic effect is modulated via a serotonin 2C receptor interaction. ACS Chem. Neurosci. 6, 1186-1197. doi: $10.1021 / \operatorname{cn} 500318 \mathrm{q}$

Schellekens, H., van Oeffelen, W. E., Dinan, T. G., and Cryan, J. F. (2013). Promiscuous dimerization of the growth hormone secretagogue receptor (GHS-R1a) attenuates ghrelin-mediated signaling. J. Biol. Chem. 288, 181-191. doi: 10.1074/jbc.M112.382473
Schmidt, H. D., McFarland, K. N., Darnell, S. B., Huizenga, M. N., Sangrey, G. R., Cha, J. H., et al. (2015). ADAR2-dependent GluA2 editing regulates cocaine seeking. Mol. Psychiatry 20, 1460-1466. doi: 10.1038/mp. 2014.134

Shirahase, T., Watanabe, Y., Tsujimura, A., Kwak, S., Yamamoto, T., Kanamura, N., et al. (2018). Ethanol preference and drinking behavior are controlled by RNA editing in the nucleus accumbens. Front. Behav. Neurosci. 12:331. doi: 10.3389/fnbeh.2018.00331

Simmons, M., Meador-Woodruff, J. H., and Sodhi, M. S. (2010). Increased cortical expression of an RNA editing enzyme occurs in major depressive suicide victims. Neuroreport 21, 993-997. doi: 10.1097/WNR.0b013e32833f $11 \mathrm{c} 3$

Sodhi, M. S., Burnet, P. W., Makoff, A. J., Kerwin, R. W., and Harrison, P. J. (2001). RNA editing of the 5-HT(2C) receptor is reduced in schizophrenia. Mol. Psychiatry 6, 373-379. doi: 10.1038/sj.mp.4000920

Spoida, K., Masseck, O. A., Deneris, E. S., and Herlitze, S. (2014). Gq/5-HT2c receptor signals activate a local GABAergic inhibitory feedback circuit to modulate serotonergic firing and anxiety in mice. Proc. Natl. Acad. Sci. U.S.A. 111, 6479-6484. doi: 10.1073/pnas.1321576111

Stamm, S., Gruber, S. B., Rabchevsky, A. G., and Emeson, R. B. (2017). The activity of the serotonin receptor $2 \mathrm{C}$ is regulated by alternative splicing. Hum. Genet. 136, 1079-1091. doi: 10.1007/s00439-017-1826-3

Tecott, L. H., Sun, L. M., Akana, S. F., Strack, A. M., Lowenstein, D. H., Dallman, M. F., et al. (1995). Eating disorder and epilepsy in mice lacking 5-HT2c serotonin receptors. Nature $374,542-546$. doi: 10.1038/374542a0

Tohda, M. (2014). Serotonin $2 \mathrm{C}$ receptor as a superhero: diversities and talents in the RNA universe for editing, variant, small RNA and other expected functional RNAs. J. Pharmacol. Sci. 126, 321-328. doi: 10.1254/jphs.14R06CR

Uchida, H., Matsumura, S., Okada, S., Suzuki, T., Minami, T., and Ito, S. (2017). RNA editing enzyme ADAR2 is a mediator of neuropathic pain after peripheral nerve injury. FASEB J. 31, 1847-1855. doi: 10.1096/fj.201600950R

van de Wouw, M., Stilling, R. M., Peterson, V. L., Ryan, F. J., Hoban, A. E., Shanahan, F., et al. (2019). Host microbiota regulates central nervous system serotonin receptor 2C editing in rodents. ACS Chem. Neurosci. 10, 3953-3960. doi: 10.1021/acschemneuro.9b00414

Wang, Q., O’Brien, P. J., Chen, C. X., Cho, D. S., Murray, J. M., and Nishikura, K. (2000). Altered G protein-coupling functions of RNA editing isoform and splicing variant serotonin2C receptors. J. Neurochem. 74, 1290-1300. doi: 10.1046/j.1471-4159.2000.741290.x

Watanabe, Y., Yoshimoto, K., Tatebe, H., Kita, M., Nishikura, K., Kimura, M., et al. (2014). Enhancement of alcohol drinking in mice depends on alterations in RNA editing of serotonin 2C receptors. Int. J. Neuropsychopharmacol. 17, 739-751. doi: 10.1017/S1461145713001545

Weissmann, D., van der Laan, S., Underwood, M. D., Salvetat, N., Cavarec, L., Vincent, L., et al. (2016). Region-specific alterations of A-to-I RNA editing of serotonin $2 \mathrm{c}$ receptor in the cortex of suicides with major depression. Transl. Psychiatry 6:e878. doi: 10.1038/tp.2016.121

Werry, T. D., Loiacono, R., Sexton, P. M., and Christopoulos, A. (2008). RNA editing of the serotonin $5 \mathrm{HT} 2 \mathrm{C}$ receptor and its effects on cell signalling, pharmacology and brain function. Pharmacol. Ther. 119, 7-23. doi: 10.1016/ j.pharmthera.2008.03.012

Yoshimoto, K., and Komura, S. (1989). Genetic differences in the effects of voluntary ethanol consumption on brain monoamine levels in inbred strains of mice, C57BL/6J, C3H/He and DBA/2Cr. Alcohol Alcohol. 24, 225-229.

Yoshimoto, K., and McBride, W. J. (1992). Regulation of nucleus accumbens dopamine release by the dorsal raphe nucleus in the rat. Neurochem. Res. 17, 401-407. doi: 10.1007/bf00969884

Yoshimoto, K., Watanabe, Y., Tanaka, M., and Kimura, M. (2012). Serotonin2C receptors in the nucleus accumbens are involved in enhanced alcohol-drinking behavior. Eur. J. Neurosci. 35, 1368-1380. doi: 10.1111/j.1460-9568.2012. 08037.x

Zaidan, H., and Gaisler-Salomon, I. (2015). Prereproductive stress in adolescent female rats affects behavior and corticosterone levels in second-generation offspring. Psychoneuroendocrinology 58, 120-129. doi: 10.1016/j.psyneuen. 2015.04.013

Zaidan, H., Ramaswami, G., Golumbic, Y. N., Sher, N., Malik, A., Barak, M., et al. (2018). A-to-I RNA editing in the rat brain is age-dependent, region-specific 
and sensitive to environmental stress across generations. BMC Genomics 19:28. doi: 10.1186/s12864-017-4409-8

Zaniewska, M., Alenina, N., Wydra, K., Frohler, S., Kusmider, M., McCreary, A. C., et al. (2015). Discovering the mechanisms underlying serotonin (5HT)2A and 5-HT2C receptor regulation following nicotine withdrawal in rats. J. Neurochem. 134, 704-716. doi: 10.1111/jnc.13192

Zhang, Z., Shen, M., Gresch, P. J., Ghamari-Langroudi, M., Rabchevsky, A. G., Emeson, R. B., et al. (2016). Oligonucleotide-induced alternative splicing of serotonin $2 \mathrm{C}$ receptor reduces food intake. EMBO Mol. Med. 8, 878-894. doi: 10.15252/emmm.201506030
Conflict of Interest: The authors declare that the research was conducted in the absence of any commercial or financial relationships that could be construed as a potential conflict of interest.

Copyright $\odot 2020$ Tanaka and Watanabe. This is an open-access article distributed under the terms of the Creative Commons Attribution License (CC BY). The use, distribution or reproduction in other forums is permitted, provided the original author(s) and the copyright owner(s) are credited and that the original publication in this journal is cited, in accordance with accepted academic practice. No use, distribution or reproduction is permitted which does not comply with these terms. 